\title{
PASSENGER CHOICE DECISIONS AT A REGIONAL AIRPORT IN SOUTH AFRICA
}

\author{
GERT HEYNS* \\ STEPHEN CARSTENS** \\ *gjheyns@uj.ac.za \\ Institute of Transport and Logistics Studies (Africa) \\ University of Johannesburg \\ South Africa \\ **stephcar@global.co.za \\ Institute of Transport and Logistics Studies (Africa) \\ University of Johannesburg \\ South Africa
}

\begin{abstract}
The choices made by departing air transportation passengers from multiple airport regions impact on the strategies of competing airlines, airport operators and planners and local authorities. For these stakeholders it is important to understand which determinants influence passenger decision-making. The purpose of this article is to determine the main factors which influence airport choice decisions at a regional airport in the Greater Johannesburg area in South Africa.
\end{abstract}

\section{INTRODUCTION}

The Greater Johannesburg region, situated in the Gauteng province of South Africa, has one major international airport, OR Tambo International Airport (ORTIA) and a number of smaller regional airports. These regional airports include: Lanseria International Airport (LIA), Grand Central (GCJ), Rand (QRA) and Wonderboom (PRY). ORTIA provides a mixture of long- and short-haul services and is served by a combination of full-service scheduled carriers and low-cost carriers (LCCs).ORTIA is owned by the Airports Company South Africa (ACSA) which is majority owned by the South African Government. LIA on the other hand, is privately owned and is served by charter airlines and LCCs.

Although many variants exist, LCCs are typically characterised by service features such as simplified, single-class services with high density seating and no free in-flight services such as food and drinks. In many markets LCCs also operate from underutilised secondary airports which allows for operational costs savings associated with faster aircraft turnarounds and lower airport charges (Pels, Njegovan \& Behrens, 2009). Usually, these secondary airports are located some distance from the Central Business District (CBD) and main city airport. LIA is situated west of Johannesburg and is approximately $55 \mathrm{~km}$ from ORTIA, which is located to the east of the city. 
Kulula.com, an LCC, started operating from LIA in 2006, creating competition between LLC and full cost carriers (FCC) served by ORTIA. Until June 2011, Kulula.com, which also operates flights from ORTIA, was the only LCC operating direct flights to Cape Town and Durban from LIA. Competition in the LCC market and between ORTIA and LIA has intensified since Mango, another LCC, started to operate flights between LIA and Cape Town in June 2011.

It is of great concern to the airlines and the airport operators at ORTIA and LIA to understand the determinants that influence a passenger's decision as to which airport to use for flights on the Cape Town and Durban routes. Passenger migrations between airports impact on the airport operation's capacities. The airport that gains additional passengers needs to be able to supply sufficient capacities in terms of airport operations and the airport that loses passengers needs to take this into account in future capacity and financial planning strategies. The impact on airlines is apparent - the airline may need to reduce services at the airport losing passengers and increase services at the airport that gains passengers. The level of the impact depends on a number of factors such as the number of passengers, the available capacities at the airports, etc.

This phenomenon is not specific to South Africa and globally airlines and airport operators face the same challenges to understand which factors influence passengers' decisionmaking process in airport choice. The decision of a passenger to use an alternative airport depends on various factors and the objective of this study is to identify the most important factors that passengers take into account in their decision to use either ORTIA or LIA.

\section{LITERATURE REVIEW}

Many studies relating to the choice of an airport in a multiple airport environment have been conducted and reveal similar factors that influence the passenger's decision to use a specific airport. In certain instances LCCs would use underutilised regional airports and provide cheaper flights. Francis and Humphreys (2002) found that passengers are willing to travel further to access cheaper flights. However, this is not necessarily the case with LIA, as the LCC (e.g. Kulula.com) sometimes offer cheaper flights from both LIA and ORTIA.

Barrett (2004) found that LCCs consider airport choice factors to include:low airport charges, quick aircraft turnarounds, simple terminals, rapid check-in facilities, good passenger facilities and airport accessibility. These decision factors indicate that LCCs focus on providing higher service levels at a lower fare to passengers, who in turn may use these considerations in their airport decision.

Lian and Rønnevik (2011) found that airport access time, flight frequency, differences in air fare, type of aircraft and purpose of travel are all determinants taken into account by 
passengers in their airport choice decision. In addition, Harvey (1987), as cited in Lian and Rønnevik (2011) maintained that the purpose of travel (e.g. business and leisure travel) impacts on certain decision factors such as travel time and that leisure travellers have a lower valuation of travel time. Purpose of travel is also indicated as an important factor by LengOng and Tan (2010).

Travel time to the airport is very important to the passenger as indicated by Barbot (2006) who found that the location of the airport plays a major role in the passenger's airport decision (i.e. the distance travelled in general impacts on the travel time). Therefore, the geographical location of the airport may be a more attractive proposition to passengers in the vicinity of the airport.

Hess, Adler and Polak (2007) suggest that airport access time plays a major role in the passenger's airport choice. According to Fuellhart (2007), travellers are willing to spend more time on access drives to larger airports to take advantage of lower fares and more convenient airport services. This is generally referred to as airport or traffic leakage. The degree of airport leakage is influenced by the varying access time and associated level of service at the different airports. Lian and Rønnevik (2011) highlight that the important aspects of level of service are: 1) fare; 2 ) direct or indirect service - i.e. flying time; (3) aircraft type; and 4) frequency, timing of flights and capacity offered.

These findings are corroborated by Ishii, Jun and Van Dender (2009) whose research indicates that non-cost factors such as airport access time, airport delay, flight frequency, the availability of particular airport-airline combinations, and early arrival times significantly impact on the passenger's airport choice decision. An important aspect of the ORTIA-LIA decision relates to access time as a result of the prevalence of major levels of congestion on the main arteries to these airports. There are however, alternatives to motor car travel such as the Gautrain that currently feeds into ORTIA from the Sandton CBD. In addition, the implementation of a road tolling system on the Gauteng freeways will in future add to the access cost. Access time and the associated costs are highlighted by research by Barbot (2009) as factors that passengers take into account when choosing airports.

Although numerous research studies have identified a range of factors that influence the passenger's airport decision, the decision-making process is not simple and straightforward, e.g. a passenger will not necessarily always select the airport where the cheapest flights can be found. This is evident from the research by Ishii, et al. (2009) who found that passengers do not select an airline and an airport, but rather consider the airport-airline attributes. Hess (2010) reported that passengers may also complement their decision with additional factors that were not necessarily part of the survey, e.g. the size of the airport.According to Hess (2010) some passengers have a dislike of larger airports because of the perceived potential for delays and the higher levels of stress in using the larger airport. 


\section{STUDY METHODOLOGY}

The purpose of this article is to determine the main factors that influence airport choice decisions at a regional airport in the Greater Johannesburg area in South Africa. Various approaches such as focus groups or surveys may be used to identify the determining factors. For this research, a paper-based survey based on a sample of departing passengers at LIA was used to determine the most important attributes. An independent research company was used to complete the survey. At the time of the survey only Kulula.com offered domestic services from LIA to Cape Town International Airport (CTIA) and from LIA to Durban International Airport (DIA). Since June 2011 Mango also offers domestic services between LIA and CTIA. LIA is the most important secondary airport in South Africa.

A random sample survey of 210 departing passengers was completed over the period of 29 September to 4 October 2010. The sample of passengers was selected to be representative of the weekly departure schedule of Kulula.com as depicted in Table 1. The sample framework (number of surveys and the survey times) is presented in Table 2.

Table 1: Kulula.com's weekly departure schedule from LIA

\begin{tabular}{|l|c|}
\hline \multicolumn{2}{|c|}{ Mon - Wednesday } \\
\hline Cape Town & $06: 00$ \\
\hline Durban & $06: 15$ \\
\hline Cape Town & $07: 55$ \\
\hline Cape Town & $08: 30$ \\
\hline Durban & $11: 20$ \\
\hline Durban & $13: 50$ \\
\hline Cape Town & $14: 40$ \\
\hline Cape Town & $17: 10$ \\
\hline Durban & $18: 25$ \\
\hline Cape Town & $20: 00$ \\
\hline Durban & $20: 15$ \\
\hline
\end{tabular}

\begin{tabular}{|l|c|}
\hline \multicolumn{2}{|c|}{ Thursday, Friday } \\
\hline Cape Town & $06: 00$ \\
\hline Durban & $06: 15$ \\
\hline Cape Town & $07: 55$ \\
\hline Cape Town & $08: 30$ \\
\hline Durban & $11: 20$ \\
\hline Durban & $13: 50$ \\
\hline Cape Town & $14: 40$ \\
\hline Cape Town & $17: 10$ \\
\hline Durban & $18: 25$ \\
\hline Cape Town & $20: 00$ \\
\hline Durban & $20: 15$ \\
\hline Cape Town & $21: 45$ \\
\hline Durban & $22: 30$ \\
\hline
\end{tabular}

\begin{tabular}{|l|c|}
\hline \multicolumn{2}{|c|}{ Saturday } \\
\hline Cape Town & $06: 55$ \\
\hline Cape Town & $07: 30$ \\
\hline Durban & $10: 20$ \\
\hline Durban & $12: 50$ \\
\hline Cape Town & $13: 40$ \\
\hline Cape Town & $16: 10$ \\
\hline Durban & $17: 25$ \\
\hline
\end{tabular}

\begin{tabular}{|l|c|}
\hline \multicolumn{2}{|c|}{ Sunday } \\
\hline Cape Town & $06: 55$ \\
\hline Cape Town & $07: 30$ \\
\hline Durban & $10: 20$ \\
\hline Durban & $12: 50$ \\
\hline Cape Town & $13: 40$ \\
\hline Cape Town & $16: 10$ \\
\hline Durban & $17: 25$ \\
\hline Cape Town & $19: 00$ \\
\hline Durban & $19: 15$ \\
\hline Cape Town & $20: 45$ \\
\hline Durban & $21: 30$ \\
\hline
\end{tabular}


Table 2: Sample framework at LIA

\begin{tabular}{|c|c|c|c|c|}
\hline \multirow{2}{*}{$\begin{array}{c}\text { Departure } \\
\text { time }\end{array}$} & \multicolumn{5}{|c|}{ Week day } \\
\hline & Sunday & Monday & Tuesday & Wednesday \\
\hline $06: 00$ & & & 15 & \\
\hline $06: 15$ & & & 15 & \\
\hline $07: 55$ & & & 15 & \\
\hline $11: 20$ & & & & 15 \\
\hline $12: 50$ & 15 & & & \\
\hline $13: 40$ & 15 & & & \\
\hline $13: 50$ & & & & 15 \\
\hline $14: 40$ & & & & 15 \\
\hline $17: 10$ & & 15 & & \\
\hline $17: 25$ & 15 & & & \\
\hline $18: 25$ & & 15 & & \\
\hline $19: 00$ & 15 & & & \\
\hline $20: 00$ & & 15 & & \\
\hline $20: 15$ & & 15 & & \\
\hline
\end{tabular}

In addition, the sample reflected approximately even proportions in terms of the gender of the respondent as well as the destination of the respondent, i.e. Cape Town or Durban. The sample included respondents resident in Gauteng as well as other provinces. Each respondent was requested to complete a questionnaire which included attributes relating to the following areas of interest: 1) demographics, 2) price, 3) service, 4) convenience, and 5) safety. The compilation of the 18 attributes included in the questionnaire resulted from a literature study, discussions with aviation experts and personal experience. The questionnaire was subjected to pre-testing by a panel of academics and aviation experts to identify any vagueness and uncertainty. Certain questions were adjusted to ensure clarity and correct interpretation. Respondents were also given the opportunity to add additional attributes.

Respondents were requested to complete a 4-point Likert-type scale to rank the impact of each attribute on their decision to use LIA. The response format was anchored by to no extent (1) and to a large extent (4). This is a forced choice method where the middle option of undecided or neutral is not available.

The demographic characteristics of the respondents who participated in the questionnaire are depicted in Table 3 and Table 4 . More males (56\%) than females (44\%) were interviewed. The destination split between CTIA (49\%) and DIA (51\%) was fairly based with the majority of respondents from Gauteng (46\%) and an equal spread of respondents from KwaZuluNatal (24\%) and the Western Cape (26\%). The majority of respondents were on Business (51\%) and Leisure (37\%) trips. 
Table 3: Purpose of travel

\begin{tabular}{|l|c|c|c|c|c|c|c|c|}
\hline \multirow{2}{*}{ Purpose of Travel } & \multicolumn{3}{|c|}{ LIA to CPIA } & \multicolumn{3}{c|}{ LIA to DIA } & \multirow{2}{*}{ Grand Total } & \multirow{2}{*}{$\%$} \\
\cline { 2 - 8 } & Female & Male & Total & Female & Male & Total & \\
\hline Business & 17 & 40 & 57 & 16 & 34 & 50 & 107 & $51 \%$ \\
\hline Leisure & 21 & 16 & 37 & 25 & 16 & 41 & 78 & $37 \%$ \\
\hline Sport & & 1 & 1 & & 1 & 1 & 2 & $1 \%$ \\
\hline Student & & 1 & 1 & 1 & 2 & 3 & 4 & $2 \%$ \\
\hline VFR & 4 & 2 & 6 & 8 & 5 & 13 & 19 & $9 \%$ \\
\hline \multicolumn{1}{|c|}{ Total } & $\mathbf{4 2}$ & $\mathbf{6 0}$ & $\mathbf{1 0 2}$ & $\mathbf{5 0}$ & $\mathbf{5 8}$ & $\mathbf{1 0 8}$ & $\mathbf{2 1 0}$ & $\mathbf{1 0 0 \%}$ \\
\hline
\end{tabular}

Table 4: Place of residence

\begin{tabular}{|c|c|c|c|c|c|c|c|c|}
\hline \multirow{2}{*}{ Place of Residence } & \multicolumn{3}{|c|}{ LIA to CPIA } & \multicolumn{3}{c|}{ LIA to DIA } & \multirow{2}{*}{ Total } & \multirow{2}{*}{$\%$} \\
\cline { 2 - 8 } & Female & Male & Total & Female & Male & Total & & \\
\hline Gauteng & 15 & 28 & 43 & 22 & 31 & 53 & 96 & $46 \%$ \\
\hline KwaZulu-Natal & 1 & & 1 & 25 & 24 & 49 & 50 & $24 \%$ \\
\hline Limpopo & & & & & 1 & 1 & 1 & $0 \%$ \\
\hline North West & 1 & & 1 & 2 & 2 & 4 & 5 & $2 \%$ \\
\hline Out of RSA & 1 & 1 & 2 & 1 & & 1 & 3 & $1 \%$ \\
\hline Western Cape & 24 & 31 & 55 & & & & 55 & $26 \%$ \\
\hline Total & $\mathbf{4 2}$ & $\mathbf{6 0}$ & $\mathbf{1 0 2}$ & $\mathbf{5 0}$ & $\mathbf{5 8}$ & $\mathbf{1 0 8}$ & $\mathbf{2 1 0}$ & $\mathbf{1 0 0 \%}$ \\
\hline
\end{tabular}

The initial frequency analysis (percentage) of all the factors is depicted in Table 5.

Table 5: Frequency analysis of determining factors

\begin{tabular}{|l|c|c|c|c|}
\hline \multicolumn{1}{|c|}{ Factor } & To no extent & $\begin{array}{c}\text { To a small } \\
\text { extent }\end{array}$ & $\begin{array}{c}\text { To a moderate } \\
\text { extent }\end{array}$ & $\begin{array}{c}\text { To a large } \\
\text { extent }\end{array}$ \\
\hline Price of ticket & 23 & 23 & 29 & 24 \\
\hline Price of parking & 48 & 21 & 16 & 16 \\
\hline Cost of transport to airport & 36 & 16 & 17 & 32 \\
\hline Destinations serviced & 13 & 11 & 23 & 52 \\
\hline On-time departure/arrival & 19 & 12 & 30 & 39 \\
\hline Frequency of service & 15 & 16 & 32 & 37 \\
\hline Seat availability & 14 & 15 & 35 & 36 \\
\hline Departure times & 15 & 15 & 32 & 38 \\
\hline Facilities at airport & 20 & 15 & 26 & 39 \\
\hline Baggage collection & 21 & 10 & 17 & 52 \\
\hline Time to \& from airport & 11 & 2 & 13 & 75 \\
\hline Ease of access & 10 & 4 & 16 & 69 \\
\hline Ease of parking & 20 & 12 & 18 & 50 \\
\hline Ease of check-in & 13 & 8 & 15 & 64 \\
\hline Airline loyalty & 23 & 13 & 38 & 27 \\
\hline Airport safety & 17 & 15 & 34 & 35 \\
\hline Parking security & 23 & 15 & 30 & 33 \\
\hline Baggage security & 17 & 15 & 29 & 38 \\
\hline
\end{tabular}


The response categories have a rank order, but the intervals between categories cannot be assumed to be equal (Jamieson, 2004). This has an inherent shortcoming in terms of the objective of the survey, i.e. the identification of the most important factors in airport choice if a frequency analysis approach is used.

For this purpose factor analysis is a better approach than frequency analysis. The objective with factor analysis is to reduce the number of variables, i.e. to obtain a more parsimonious model (Morrison, 1978). Factor analysis allows for the calculation of the latent factors as well as the factor loadings, i.e. the correlation of the attributes with the latent factors (Morrison, 1978).

A major concern is the fact that the results of this survey are discrete and therefore require the application of non-parametric procedures. However, Lubke and Muthén (2004) have argued that factor analysis is applicable to discrete, ordinal data resulting from responses to Likert-type scale questions. In addition, there is a school of thought that indicates that factor analysis, as a preliminary analysis, is acceptable.

\section{DISCUSSION OF RESULTS}

An exploratory factor analysis was done to reduce the number of attributes being considered as important by passengers in their airport decision to a more manageable number. The factor analysis was based on the correlation matrix. Darlington (1997) states that 100 or more cases (responses) should be sufficient to discover a clear factor structure. Therefore, the survey resulted in sufficient information to perform factor analysis.

The exploratory factor analysis was conducted with SPSS for Windows version 18 using the Principle Component Extraction method utilising the Varimax Rotation with Kaiser Normalisation. The Kaiser-Meyer-Olkin (KMO) and Bartlett tests indicated that the intercorrelation matrix would allow for a factor analysis (refer to Table 6).

Table 6: KMO and Bartlett's Test

\begin{tabular}{|l|l|r|}
\hline \multicolumn{2}{|c|}{ Kaiser-Meyer-Olkin Measure of Sampling Adequacy. } & 0.892 \\
\hline \multirow{3}{*}{ Bartlett's Test of Sphericity } & Approx. Chi-Square & 1895.744 \\
\cline { 2 - 3 } & df & 153 \\
\cline { 2 - 3 } & Sig. & 0.000 \\
\hline
\end{tabular}

The KMO measure of sampling accuracy is 0.892 which indicates that the sample is more than adequate for factor analysis. According to Field (2009) a value of between 0.7 and 0.8 is considered to be good and a value between 0.8 and 0.9 is considered to be great. Bartlett's test of sphericity was significant, further indicating that the level of factorability is acceptable. 
The initial factor analysis resulted in the identification of four latent factors with eigenvalues greater than 1, which accounts for $68.5 \%$ of the variation (refer to Table 7). However, Costello and Osborne (2005) state that using this criterion (eigenvalues greater than 1) for the selection of the factors is not very accurate. They suggest that the scree plot provides much more information for the selection of the number of factors. Field (2009) also recommends that the scree plot be used if analysis has 200 or more participants. The scree plot for the initial factor analysis is depicted in Figure 1.

Table 7: Initial factor analysis - Total variance

\begin{tabular}{|c|c|c|c|c|c|c|c|c|c|}
\hline \multirow{2}{*}{ Component } & \multicolumn{3}{|c|}{ Initial Eigenvalues } & \multicolumn{3}{|c|}{ Extraction Sums of Squared Loadings } & \multicolumn{3}{|c|}{ Rotation Sums of Squared Loadings } \\
\hline & Total & $\begin{array}{c}\% \text { of } \\
\text { Variance } \\
\end{array}$ & $\begin{array}{c}\text { Cumulative } \\
\%\end{array}$ & Total & $\%$ of Variance & Cumulative $\%$ & Total & $\begin{array}{c}\% \text { of } \\
\text { Variance } \\
\end{array}$ & $\begin{array}{c}\text { Cumulative } \\
\%\end{array}$ \\
\hline 1 & 7.806 & 43.368 & 43.368 & 7.806 & 43.368 & 43.368 & 3.727 & 20.705 & 20.705 \\
\hline 2 & 1.818 & 10.097 & 53.466 & 1.818 & 10.097 & 53.466 & 3.69 & 20.498 & 41.203 \\
\hline 3 & 1.7 & 9.446 & 62.911 & 1.7 & 9.446 & 62.911 & 2.873 & 15.959 & 57.162 \\
\hline 4 & 1.011 & 5.615 & 68.526 & 1.011 & 5.615 & 68.526 & 2.045 & 11.364 & 68.526 \\
\hline 5 & 0.902 & 5.011 & 73.537 & & & & & & \\
\hline 6 & 0.749 & 4.159 & 77.695 & & & & & & \\
\hline 7 & 0.567 & 3.148 & 80.843 & & & & & & \\
\hline 8 & 0.486 & 2.702 & 83.545 & & & & & & \\
\hline 9 & 0.485 & 2.694 & 86.24 & & & & & & \\
\hline 10 & 0.45 & 2.501 & 88.741 & & & & & & \\
\hline 11 & 0.374 & 2.08 & 90.82 & & & & & & \\
\hline 12 & 0.355 & 1.971 & 92.791 & & & & & & \\
\hline 13 & 0.318 & 1.765 & 94.556 & & & & & & \\
\hline 14 & 0.25 & 1.387 & 95.943 & & & & & & \\
\hline 15 & 0.213 & 1.181 & 97.124 & & & & & & \\
\hline 16 & 0.201 & 1.116 & 98.24 & & & & & & \\
\hline 17 & 0.171 & 0.952 & 99.192 & & & & & & \\
\hline 18 & 0.145 & 0.808 & 100 & & & & & & \\
\hline
\end{tabular}

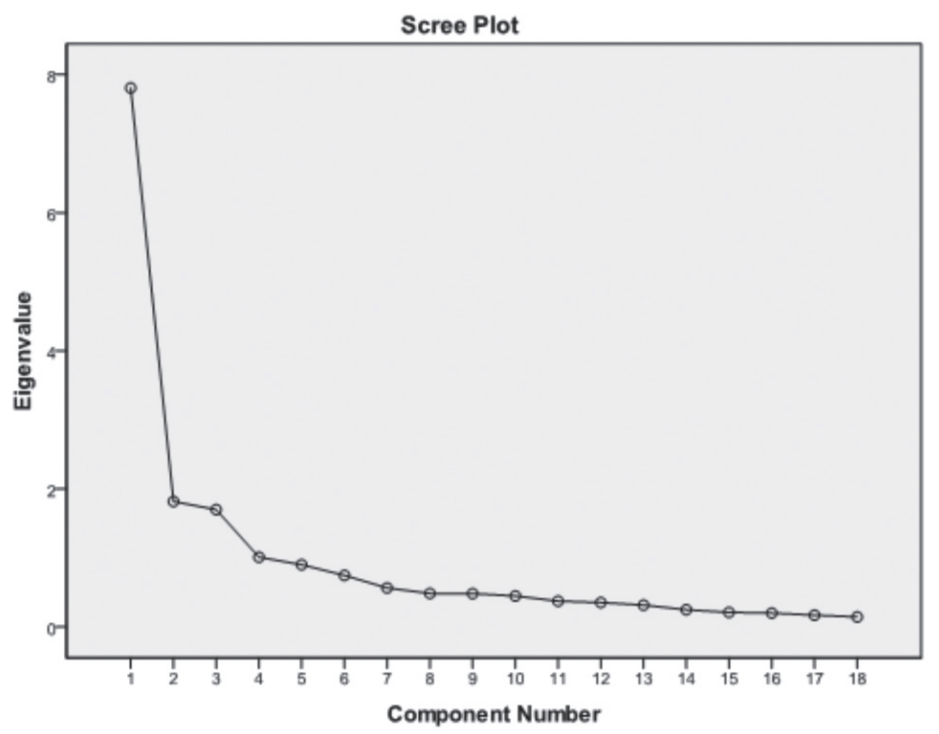

Figure 1: Scree plot for Initial Factor Analysis 
The scree plot indicates that only three factors should be retained, i.e. the number of data points above the 'break'. Costello and Osborne (2005) suggest a sequential procedure if uncertainty exists in terms of the number of factors to retain. This entails running confirmatory factor analysis (CFA) with the number of factors below and above the number of factors indicated by the scree test. Costello and Osborne (2005) further suggest that the cleanest factor structure (after rotation) is based on factor loadings above 0.3 , no cross-loadings and no factors with fewer than three variables.

A CFA for three and four factors was subsequently conducted using the Principle Component Extraction method utilising the Varimax Rotation with Kaiser Normalisation. The results from CFA for three and four factors are provided in Table 8 and Table 9 respectively.

The results in Table VIII indicate a number of variables with relatively strong cross-loadings on at least two of the factors.

Table 8: Confirmatory factor analysis (three factors)

\begin{tabular}{|l|r|r|r|}
\hline \multirow{2}{*}{} & \multicolumn{3}{|c|}{ Component } \\
\cline { 2 - 4 } & \multicolumn{1}{|c|}{1} & \multicolumn{1}{c|}{2} & \multicolumn{1}{c|}{3} \\
\hline Price of ticket & 0.146 & -0.088 & 0.746 \\
\hline Price of parking & 0.133 & 0.118 & 0.825 \\
\hline Cost of transport to airport & 0.008 & 0.348 & 0.776 \\
\hline Destinations serviced & 0.519 & 0.388 & 0.086 \\
\hline On-time dep/arr & 0.814 & 0.132 & 0.031 \\
\hline Frequency of service & 0.845 & 0.169 & 0.106 \\
\hline Seat availability & 0.765 & 0.198 & 0.142 \\
\hline Departure times & 0.84 & 0.096 & 0.097 \\
\hline Facilities at airport & 0.591 & 0.448 & \\
\hline Baggage collection & 0.351 & 0.627 & 0.175 \\
\hline Time to/from airport & 0.136 & 0.808 & -0.013 \\
\hline Ease of access & 0.168 & 0.8 & 0.023 \\
\hline Ease of parking & 0.123 & 0.739 & 0.222 \\
\hline Ease of check-in & 0.345 & 0.809 & 0.076 \\
\hline Airline loyalty & 0.504 & 0.302 & 0.104 \\
\hline Airport safety & 0.6 & 0.579 & 0.062 \\
\hline Parking security & 0.473 & 0.452 & 0.278 \\
\hline Baggage security & 0.542 & 0.604 & 0.153 \\
\hline
\end{tabular}


Table 9: Confirmatory factor analysis (four factors)

\begin{tabular}{|l|r|r|r|r|}
\hline \multirow{2}{*}{} & \multicolumn{4}{|c|}{ Component } \\
\cline { 2 - 5 } & \multicolumn{1}{|c|}{1} & \multicolumn{1}{|c|}{2} & \multicolumn{1}{c|}{3} & \multicolumn{1}{c|}{4} \\
\hline Price of ticket & 0.18 & -0.064 & -0.029 & 0.754 \\
\hline Price of parking & 0.093 & 0.075 & 0.169 & 0.819 \\
\hline Cost of transport to aimport & -0.02 & 0.318 & 0.147 & 0.776 \\
\hline Destinations serviced & 0.574 & 0.454 & 0.044 & 0.108 \\
\hline On-time dep/arr & 0.767 & 0.104 & 0.296 & 0.024 \\
\hline Frequency of service & 0.825 & 0.167 & 0.248 & 0.108 \\
\hline Seat availability & 0.753 & 0.202 & 0.221 & 0.145 \\
\hline Departure times & 0.828 & 0.1 & 0.218 & 0.099 \\
\hline Facilities at airport & 0.51 & 0.39 & 0.372 & -0.01 \\
\hline Baggage collection & 0.276 & 0.571 & 0.342 & 0.17 \\
\hline Time to/from airport & 0.158 & 0.844 & 0.098 & 0.007 \\
\hline Ease of access & 0.184 & 0.83 & 0.118 & 0.042 \\
\hline Ease of parking & 0.03 & 0.664 & 0.352 & 0.214 \\
\hline Ease of checkin & 0.273 & 0.76 & 0.357 & 0.075 \\
\hline Airline loyalty & 0.269 & 0.096 & 0.682 & 0.055 \\
\hline Airport safety & 0.358 & 0.373 & 0.757 & 0.016 \\
\hline Parking security & 0.222 & 0.231 & 0.74 & 0.227 \\
\hline Baggage security & 0.334 & 0.427 & 0.676 & 0.115 \\
\hline
\end{tabular}

The results of the four-factor CFA indicate a reduction in the number of variables with crossloadings and a much clearer dominance of variable loadings on factors 2 and 3 . It seems that four factors fit the data better than three factors. However, the objective of factor analysis is to obtain a more parsimonious model, i.e. a reduction in the number of variables that have a significant influence on a passenger's airport decision.

Variable loadings on factors in excess of 0.512 are considered as statistically significant for a sample size of 100 (Field, 2009). Inspection of the CFA results indicate that the factor loadings for only one variable (i.e. Facilities at the airport) are below 0.512 for all four factors. However, if the minimum loading criterion is increased to 0.7 the resultant data set (variables) is as depicted in Table 10. 
Table 10: Decision variables

\begin{tabular}{|l|l|}
\hline Factor $\mathbf{1}$ (factor loadings $\mathbf{> 0 . 7})$ & Factor $\mathbf{2}$ (factor loadings $>\mathbf{0 . 7}$ ) \\
On time arrival/departure & Time to/from airport \\
Frequency of service & Ease of access \\
Seat availability & Ease of check-in \\
Departure time & \\
\hline $\begin{array}{l}\text { Factor } \mathbf{3} \text { (factor loadings } \mathbf{> 0 . 7} \text { ) } \\
\text { Airport Safety } \\
\text { Parking security }\end{array}$ & $\begin{array}{l}\text { Factor } \mathbf{4} \text { (factor loadings }>\mathbf{0 . 7} \text { ) } \\
\text { Price of ticket } \\
\text { Price of parking } \\
\text { Cost of transport to the airport }\end{array}$ \\
\hline
\end{tabular}

This implies that the passenger at LIA decision is influenced mostly by 12 variables that can be represented by four latent factors:

1. Airline efficiencies

2. Airport location and services

3. Safety and security

4. Cost

The results of this study to determine the important factors that influence passengers' airport choice decision, closely reflect the results reported from similar studies conducted elsewhere (refer to literature review). In addition, the results of this study indicate that a combination of airline-airport attributes are being considered by passengers in their airport choice decision (Ishii, et al. 2009). However, airport security seems to be an important factor in the airport choice of passengers using LIA. This factor was not reported by similar studies elsewhere as being significant in the passenger's decision to use a specific airport.

Another aspect of the data researched is the influence of the demography of the sample on the results. Therefore, sub-sections of the data, based on the demographic variables, were evaluated to determine if significant differences exist in terms of the importance of attributes (i.e. to test whether the data originated from different distributions). The focus was mainly on gender and purpose of travel since research has indicated that distinct differences exist in terms of the importance of variables in the airport decision. This was achieved through factor analysis on the different sub-sections.

The analysis on the complete data set for the sub-sections relating to gender, indicates that the four factors (components) explained $71.8 \%$ and $68.8 \%$ of the variance for females and males respectively. If the same minimum variable loading criterion $(>0.7)$ is applied the analysis resulted in 13 and 10 variables being retained for females and males respectively. 
Compared to the complete data analysis results, the factors as well as the variable loadings on the factors differ. The factors and variable loadings for the male respondents differ from those of the female respondents. A comparison between the factors and variables that load onto the factors (>0.7) of female and male respondents is shown in Table 11.

Table 11: Decision factors by gender

\begin{tabular}{|c|c|c|}
\hline \multirow{2}{*}{ Factor } & \multicolumn{2}{|c|}{ Gender } \\
\hline & Female & Male \\
\hline Factor 1 & $\begin{array}{l}\text { Baggage collection } \\
\text { Time to/from the airport } \\
\text { Ease of access } \\
\text { Ease of parking } \\
\text { Ease of check-in }\end{array}$ & $\begin{array}{l}\text { On-time arrival/departure } \\
\text { Frequency of service } \\
\text { Seat availability } \\
\text { Departure times }\end{array}$ \\
\hline Factor 2 & $\begin{array}{l}\text { On-time arrival/departure } \\
\text { Frequency of service } \\
\text { Seat availability } \\
\text { Departure times }\end{array}$ & $\begin{array}{l}\text { Time to/from the airport } \\
\text { Ease of access }\end{array}$ \\
\hline Factor 3 & $\begin{array}{l}\text { Airline loyalty } \\
\text { Airport safety } \\
\text { Parking security }\end{array}$ & Parking security \\
\hline Factor 4 & Price of parking & $\begin{array}{l}\text { Price of ticket } \\
\text { Price of parking } \\
\text { Cost of transport to the } \\
\text { airport }\end{array}$ \\
\hline
\end{tabular}

The cost of transport to the airport is not considered important by female passengers but plays a role in male passengers' decision-making. Furthermore, male passengers view airline service effectiveness (e.g. on-time arrival/departure) as more important than do female passengers. The latent factor that explains most of the decision-making variance for female passengers relates to convenience attributes.

The analysis on the complete data set for the sub-sections related to the purpose of travel, indicates that the four factors (components) explained $73.4 \%$ and $67.5 \%$ of the variance for Business and Other travel respectively. If the same minimum variable loading criterion (>0.7) is applied the analysis resulted in 10 and 12 variables being retained for Business and Other travel respectively. Compared to the complete data analysis results, the factors as well as the variable loadings on the factors differ. The factors and variable loadings for the business passengers differ from that of the Leisure, Student and VFR (visiting friends and relatives) respondents. A comparison between the factors and variables that load onto the factors ( $>0.7$ ) of Business and Other (Leisure, Student, VFR) respondents are shown in the Table 12. 
Table 12: Decision factors by purpose of travel

\begin{tabular}{|c|l|l|}
\hline \multirow{2}{*}{ Factor } & \multicolumn{1}{|c|}{ Purpose of travel } \\
\cline { 2 - 3 } & \multicolumn{1}{|c|}{ Business } & \multicolumn{1}{|c|}{ Other } \\
\hline \multirow{3}{*}{ Factor 1} & $\begin{array}{l}\text { On-time arrival/departure } \\
\text { Frequency of service } \\
\text { Seat availability } \\
\text { Departure times }\end{array}$ & $\begin{array}{l}\text { Time to/from the airport } \\
\text { Ease of access } \\
\text { Ease of check-in }\end{array}$ \\
\hline \multirow{2}{*}{ Factor 2 } & $\begin{array}{l}\text { Ease of parking } \\
\text { Factor 3 }\end{array}$ & $\begin{array}{l}\text { On-time arrival/departure } \\
\text { Frequency of service } \\
\text { Departure times }\end{array}$ \\
\hline Factor 4 & $\begin{array}{l}\text { Time to/from the airport } \\
\text { Ease of access }\end{array}$ & $\begin{array}{l}\text { Airline loyalty } \\
\text { Airport safety } \\
\text { Baggage security }\end{array}$ \\
\hline & $\begin{array}{l}\text { Price of ticket } \\
\text { Price of parking } \\
\text { Cost of transport to the } \\
\text { airport }\end{array}$ & $\begin{array}{l}\text { Price of ticket } \\
\text { Price of parking } \\
\text { Cost of transport to the } \\
\text { airport }\end{array}$ \\
\hline
\end{tabular}

The latent factor that explains most of the decision-making variance for female passengers relates to airline service effectiveness. Airline loyalty, safety and security issues seem to be more important to passengers who are not business passengers.

\section{CONCLUSION AND RECOMMENDATIONS}

The airport choice that passengers make in the Greater Johannesburg region has a significant impact on the airports and the LCCs' ability to provide the required level of services and cost. It is therefore imperative that the stakeholders have a good understanding of the underlying factors that influence passengers' decisions on airport choice. The purpose of the study was to determine the salient factors that influence airport choice decisions of passengers which impact on competing regional airports.

The results of the study were obtained through a paper-based survey of departing passengers and the application of factor analyses to obtain the latent factors influencing the airport choice decision of a passenger.

The theoretical perspective of the research indicates that competing airlines and airport operators should be aware that the passenger's decision is influenced mostly by four latent factors, namely: 1) Airline efficiency, 2) Airport location and services, 3) Safety and security, and 4) Cost. It is further also noticeable that distinct differences exist between various subsections (i.e. gender and purpose of travel) in terms of the importance of variables in the airport choice decision. The level of importance of the individual variables of each of the latent factors can be obtained from the loadings of the variables onto the factors. 
Since the study was completed before the second LCC (i.e. Mango) started operating from LIA and the implementation of the tolling systems on the main Gauteng freeways, it is recommended that further insight into a passenger's decision-making process could be obtained by repeating the study once the tolling system has been implemented and the Gautrain high-speed rail system is fully operational. 


\section{REFERENCES}

Barbot, C. 2006. Low cost carriers, secondary airports and State aid: and economic assessment of the Ryanair-Charleroi Airport Agreement. Journal of Air Transport Management. 12:197-203.

Barbot, C. 2009. Airport and airlines competition: Incentives for vertical collusion. Transportation Research Part B. 43:952-65.

Barrett, S.D. 2004. How do the demands for airport services differ between full-service carriersand low-cost carriers? Journal of Air Transport Management.10:33-39.

Costello, A.B. \& Osborne, J. 2005. Best practices in exploratory factor analysis: four recommendations for getting the most from your analysis. Practical Assessment Research \& Evaluation. 10:1-9.

Darlington, R.B. 1997. Factor Analysis [On-line]. Available: http//www.psych.cornell.edu/ Darlington/factor.htm

Field, A. 2009. Discovering Statistics Using SPSS. Third Edition. London: Sage.

Francis, G. \& Humphreys, I. 2002. Policy issues and planning of UK regional airports. Journal of Transport Geography. 10:249-58.

Fuellhart, K. 2007. Airport catchment and leakage in multi-airport region: The case of Harrisburg International. Journal of Transport Geography.15:231-44.

Hess, S. 2010. Evidence of passenger preferences for specific types of airports. Journal of Air Transport Management.16:191-95.

Hess, S., Adler, T. \& Polak, J.W. 2007. Modelling airport and airline choice behaviour with the use of stated preference survey data. Transportation Research Part E. 43:221-33.

Ishii, J., Jun, S. \& Van Dender, C. 2009. Air travel choices in multi-airport markets. Journal of Urban Economics. 65:216-27.

Jamieson, S. 2004. Likert scales: how to (ab)use them. Medical Education. 38:1212-18.

LengOng, W. \& Tan, A.K.G. 2010. A note on the determinants of airline choice: The case of Air Asia and Malaysia Airlines. Journal of Air Transport Management. 16:209-12. 
Lian, J.I. \& Rønnevik, J. 2011. Airport competition - Regional airports losing ground to main airports. Journal of Transport Geography. 19:85-92.

Lubke, G. \& Muthén, B. 2004. Factor-analysing Likert scale data under the assumption of multivariate normality complicates a meaningful comparison of observed groups or latent classes. Structural Equation Modeling. 11:514-34.

Morrison, D. 1978. Multivariate statistical analysis. Second edition. McGraw-Hill Inc.

Pels, E., Njegovan, N. \& Behrens, C. 2009. Low-cost airlines and airport competition. Transportation Research Part E. 45:335-44.

\section{Table of acronyms and abbreviations}

\begin{tabular}{|l|l|}
\hline ACSA & Airports Company of South Africa \\
\hline CBD & Central Business District \\
\hline CFA & Confirmatory Factor Analysis \\
\hline CTIA & Cape Town International Airport \\
\hline DIA & Durban International Airport \\
\hline FCC & Full Cost Carrier \\
\hline GCJ & Grand Central Airport \\
\hline KMO & Kaiser-Meyer-Olkin measure \\
\hline LCC & Low-Cost Carrier \\
\hline LIA & Lanseria International Airport \\
\hline ORTIA & OR Tambo International Airport \\
\hline PRY & Wonderboom Airport \\
\hline QRA & Rand Airport \\
\hline VFR & Visiting Friends and Relatives \\
\hline
\end{tabular}

